\title{
Evaluation of Improved Pigeon pea (Cajanus cajan) Varieties at Adola, Guji Zone of Oromia
}

\author{
Teshale Jabessa*, Ketema Bekele \\ Oromia Agricultural Research Institute (IQQO), Bore Agricultural Research Center (BOARC), Bore, Ethiopia \\ Email address: \\ teshalejabessa@gmail.com (T. Jabessa) \\ ${ }^{*}$ Corresponding author \\ To cite this article: \\ Teshale Jabessa, Ketema Bekele. Evaluation of Improved Pigeon pea (Cajanus cajan) Varieties at Adola, Guji Zone of Oromia. Advances in \\ Biochemistry. Vol. 9, No. 1, 2021, pp. 1-5. doi: 10.11648/j.ab.20210901.11
}

Received: January 6, 2021; Accepted: January 26, 2021; Published: January 30, 2021

\begin{abstract}
A study was conducted with the objective to identify adaptable, high biomass, good quality and seed yield of Pegeon pea cultivars at Adola sub-site of Bore Agricultural research center. Four pegeon pea cultivars Tsigas, Degagsa-75, Belabas-27 and 16555 were tested in RCBD with three replications. The analysis of variation revealed that significant $(\mathrm{P}<0.05)$ differ in days to $90 \%$ maturity were observed among cultivars. Among tested cultivars Belabas 27 was significantly earlier (162 days) to maturity, while late matured cultivar was Degagsa (203 days). Analysis of variance showed highly significant differences $(\mathrm{P}<0.01)$ were observed among cultivars for number of primary branches per plant. Higher branch number was recorded for Tsigas cultivar (21.6) whereas the lowest branch number was obtained from cultivar Degagsa-75 (9.75). The cultivars were significant $(\mathrm{P}<0.05)$ differ for pod length. The long pod was recorded from cultivar $16555(5 \mathrm{~cm})$ while the short pod length was recorded from cultivar Belabas $-27(3.14 \mathrm{~cm})$. Cultivars were significant $(\mathrm{P}<0.05)$ varied for plant height. The long plant height was measured from cultivar Degagsa-75 $(159.75 \mathrm{~cm})$ followed by Tsigas $(104.9 \mathrm{~cm})$ whereas the short pant height was obtained from cultivar Belabas-27 $(78.63 \mathrm{~cm})$. Significant variations $(\mathrm{P}<0.05)$ in biomass yield between genotypes were observed (Table 2$)$. Superior biomass yield was produced from Tsigas cultivar (2.17 ton/ha) followed by cultivar 16555 (1.27 ton/ha) while the low biomass yield was obtained from Degagsa-75 cultivar (0.97 ton/ha). In addition to the nutritional values were promising particularly the crude protein (CP) content in cultivar Tsigas. Based up on its adaptability, high biomass yield, seed yield and good CP of cultivar Tsigas and 16555 is recommended for further promotion in the midland of Guji zone and similar agro- ecologies.
\end{abstract}

Keywords: Cajanus cajan, Nutritive Value, Adola, Cultivar, Variety

\section{Introduction}

Feed is the most important input in livestock production and its adequate supply throughout the year is an essential prerequisite for any substantial and sustained expansion in livestock production $[1,2]$. According to Sefa animal feeds including; natural pasture, fodder crops, fodder trees, crop residues and non-conventional feeds are used in different parts of Ethiopia [3]. Green fodder (grazing) is the major type of feed $(54.59 \%)$ followed by crop residues $(31.60 \%)$, hay $(6.81 \%)$ and industrial byproducts $(1.53 \%)$ [4].

Feed in terms of both quantity and quality is bottleneck to livestock production in Ethiopia [5]. This problem of feed shortage is more aggravated during the dry season [6]. Even during years of good rainy season, forage is not sufficient to feed livestock in the highlands [7].
Pigeon pea (Cajanus cajan (L.) is one of the leguminous crops that have been cultivated for human and livestock consumption in many parts of the world. Pigeon pea (Cajanus cajan) plant is a legume belonging to the family of "Fabaceae" or "Leguminosae" and widely used as fodder and feed for livestock [8].

Pigeon pea (Cajanus Cajan (L.) is one of the most common tropical and subtropical legumes cultivated for its edible seeds. Pigeon pea is fast growing, hardy, widely adaptable, and drought resistant [9]. Thanks to drought resistance it can be considered of utmost importance for food security regions places where rain failures are prone to occur [10]. At the end of the dry season, pigeon pea provides green forage of outstanding value when other forages have disappeared [11].

Cajanus Cajan has numerous uses in animal feeding. The leaves and pods are valuable and palatable protein-rich fodder. 
Leaves are sometimes used to replace alfalfa in ruminant's diets where alfalfa cannot be grown. Seed processing byproducts and sometimes the seeds themselves are used as livestock feed [12]. The seeds can be fed to poultry, and mixtures of pigeon pea with maize grain were successful in Hawaii. Bees actively feed on pigeon pea and produce a honey with a distinctive color (greenish) in the comb [12]. Pigeon pea is also a good host for lac insect and silkworms [13].

Pigeon pea is a tropical grain legume and is among important pulses grown for food, feed and soil fertility improvement. It is mainly grown in India and in tropical and sub tropical regions of Africa, Asia and America. It is a cheap source of protein $(20 \%)$, other soluble vitamins and essential amino acids [14]. In Southern and Eastern Africa, pigeon pea has been neglected and very little attention has been put in its research [15].

Farmers in the region still use unimproved late maturing cultivars due to poor access to improved seed [16]. Previous evaluations of Pigeon pea (cajanus cajan) has been limited to adaptation and biomass yield with respect to growth features, forage and seed productivity and forage quality in Guji Zone. Therefore, the study was undertaken the objective to identify and evaluate better adaptable, biomass yield, seed yield and quality performance of some Pigeon pea cultivars.

\section{Materials and Methods}

\subsection{Description of the Study Area}

The experiment was carried out at Adola sub-site of Bore Agricultural Research Center, Adola district, Guji Zone of Oromia. Adola district is located around at a distance of 470 $\mathrm{km}$ from Addis Ababa and $120 \mathrm{Km}$ from the zonal capital city, Negele Borena. It is an area where a mixed farming and sami- nomadic economic activity takes place, which is the major livelihood of the local people. The total area of the district is $1254.56 \mathrm{~km}^{2}$. The district is situated at $5^{\circ} 44^{\prime} 10^{\prime \prime}$ $6^{\circ} 12^{\prime} 38^{\prime \prime} \mathrm{N}$ latitudes and $38^{\circ} 45^{\prime} 10^{\prime \prime}$ - 39 $9^{\circ} 12^{\prime} 37^{\prime \prime}$ E longitudes. The district is characterized by three agro- climatic zones, namely highland $11 \%$, mid-land $29 \%$ and low-land $60 \%$ respectively. The major soil type of the district is nitosols (red basaltic soils) and orthic Acrosols [17].

\subsection{Experimental Treatments and Design}

The study was conducted using Tsigas, Degagsa, Belabas and 16555. The experiment was conducted in randomized complete block design (RCBD) with three replications. Seeds were sown in rows spaced $1 \mathrm{~m}$ with seed rate of $30 \mathrm{~kg} \mathrm{ha}$. Plot sizes of $4 \mathrm{~m} \mathrm{x} 3 \mathrm{~m}$ were used. NPS fertilizer at $100 \mathrm{~kg}$ $\mathrm{ha}^{-1}$ was uniformly applied for all treatments at sowing time.

\subsection{Data Collection}

Data were collected on days to $50 \%$ flowering, days to seed maturity, plant height, number of branches, pod per plants, pod length, seed per pods, leaf to steam ratio, biomass yield, seed yield and nutritive value. Seed yield weight was calculated at $10 \%$ moisture content. To determine grain yield, the pods were harvested from the rest rows at optimum physiological maturity by hand picking.

\subsection{Chemical Analysis}

For forage quality analysis, chopped herbage of the three replications were pooled into one and properly homogenized and one representative subsample was taken for each cultivar. The DM and ash contents were determined by oven drying at $105^{\circ} \mathrm{C}$ overnight and by igniting in a muffle furnace at $500^{\circ} \mathrm{C}$ for 6 hours, respectively. Nitrogen (N) content was determined by Kjeldahl method and $\mathrm{CP}$ was calculated as $\mathrm{N}$ x 6.25 [18]. The neutral detergent fiber (NDF), acid detergent fiber (ADF) and acid detergent lignin (ADL) fractions were analyzed according to [19].

\subsection{Statistical Analysis}

All collected data were analyzed using general linear model procedure SAS [20] version 9.1. Means were separated with least significant difference (LSD) at 5\% significant level. The statistical model for the analysis data was:

$$
\mathrm{Y}_{\mathrm{ijk}}=\mu+\mathrm{A}_{\mathrm{j}}+\mathrm{B}_{\mathrm{i}}+\mathrm{e}_{\mathrm{ijk}}
$$

Where; $\mathrm{Y}_{\mathrm{ijk}}=$ response of variable under examination, $\mu=$ overall mean, $A_{j}=$ the $j$ th factor effect of treatment, $B_{i}=$ the ith factor effect of block/ replication, $\mathrm{e}_{\mathrm{ijk}}=$ the random error.

\section{Results and Discussions}

\subsection{Analysis of Variance and Mean Performances of Pigeon Pea Cultivars}

The experiment was conducted on four improved pigeon pea (Cajanus Cajun) genotypes to select high yielder and best performing in all traits. Mean squares of various agronomic characters are presented in Table 1 whereas; mean values of different traits are presented in Table 2.

Days to $50 \%$ Flowering

Significant variations $(\mathrm{P}<0.05)$ in days to flowering between cultivars were observed (Table 2). Tsigas cultivars showed significantly shorter days to 50\% flowering (92.6 days) followed by cultivars 16555 (109 days), while Degagsa-75 cultivar was late flowered (124 days) of 50\% flowered as compared to other genotypes, this might be possibly due to genetic differences of the genotypes. This result has confirmed with the previous reports [21, 22].

Days to $90 \%$ Maturity

Analysis of variation revealed that significant variation $(\mathrm{P}<0.05)$ in days to $90 \%$ maturity was observed among cultivars (Table 2). Belabas-27 cultivar showed significantly short (162 days) to maturity followed by cultivars 16555 (186 days), while late matured cultivars was Degagsa-75 (203 days) when compared to the other cultivars.

Number of primary branches per plant

Analysis of variance showed highly significant differences $(\mathrm{P}<0.01)$ were observed among cultivars for number of 
primary branches per plant (Table 2). Higher branch number was recorded for Tsigas cultivar (21.6) whereas the lowest branch number was obtained from cultivar Degagsa-75 (9.75). This result is in conformity with the result of [23] and dis agreed with the result of [24] for different pigeon pea lines and cultivars.

Pods per plant and seeds per pod

Analysis of variance showed no significant differences among cultivars for pods per plant and seeds per pod (Table 2 ). This result was disagreed with the report of $[25,26]$.

Pod length per plant

The cultivars were significant $(\mathrm{P}<0.05)$ differ for pod length. The longest pod was recorded from cultivars 16555 (5 $\mathrm{cm})$ followed by cultivar Degagsa-75 $(5.16 \mathrm{~cm})$ while, the short pod length was recorded from cultivars Belabas-27 $(3.14 \mathrm{~cm})$. This result is in conformity with (Ezeaku et al., 2008).

\section{Plant Height}

The cultivars were significant $(\mathrm{P}<0.05)$ varied for plant height. The long plant height was measured from Dagagsa-75 cultivar $(159.75 \mathrm{~cm})$ followed by Tsigas $(104.9 \mathrm{~cm})$ cultivar whereas the short pant height was obtained from Belabas-27 $(78.63 \mathrm{~cm})$ cultivar. This result is the same with the result of (Ezeaku et al., 2008).

Leaf to Steam ratio

There were significant $(\mathrm{P}<0.05)$ differed for leaf to steam ratio of the tested cultivars. The highest leaf to steam ratio was obtained from Tsigas cultivar (1.07) followed by Belabas-27 cultivar (0.71) whereas the low leaf to steam ratio was obtained from cultivars $16555(0.67)$.

Biomass Yield

Significant variations $(\mathrm{P}<0.05)$ in biomass yield between cultivars were observed (Table 2). The long biomass yield was produced from Tsigas cultivars (2.17 ton/ha) followed by cultivars 16555 (1.27 ton/ha) while the low biomass yield was obtained from Belabas-75 cultivars ( 0.97 ton/ha).

Seed Yield

Cultivars were showed no significant differences $(\mathrm{P}<0.05)$ in seed yield performance, but numerically had different values (Table 2). The highest seed yield was recorded from Tsigas cultivars (29 qt/ha) followed by Belabas-27 cultivar (23.1 $\mathrm{qt} / \mathrm{ha}$ ), whereas the lowest seed yield was obtained from 16555 cultivar (13.2 qt/ha). This result is similar to the report of (Sharma et al., 1981) with the mean yield of $1.37 \mathrm{t} / \mathrm{ha}$.

\subsection{Chemical Composition}

Table 3, shows the chemical composition of the four pigeon pea cultivars. Cultivar Belabas-27 had the highest dry matter of (9.7) followed with cultivar 16555 recorded the lowest of (89.95). Tsigas cultivar recorded the highest CP of (30.4) while cultivar 16555 recorded the lowest crude protein of (23.1). Cultivar 16555 recorded the highest NDF of (68.6) while cultivar Tsigas recorded the lowest NDF of (47.3). Cultivar Tsigas recorded the highest ADF of (42.9) while cultivar Belabas-75 recorded the lowest NDF of (37.5). Cultivar Tsigas recorded the highest ADL of (17.4) while cultivar 16555 recorded the lowest ADL of (5.2). Cultivar Tsigas recorded the highest crude protein OM of (85.1) while cultivar 16555 recorded the lowest OM of (79.2). Cultivar Dagagsa-75 recorded the highest TASH of (9.3) while cultivar Belabas- 27 recorded the lowest TASH of (6.7). Cultivar Belabas-27 recorded the highest OM of (85.1) while cultivar 16555 recorded the lowest OM of (79.2).

Table 1. Analysis of variance for agronomic traits of the pigeon pea cultivars.

\begin{tabular}{|c|c|c|c|c|c|c|c|c|c|c|c|}
\hline \multirow{2}{*}{ Source of variations } & \multirow{2}{*}{ d.f } & \multicolumn{10}{|c|}{ Mean Squares } \\
\hline & & $50 \% D F$ & $90 \% M$ & $\mathbf{N b}$ & Ppp & PI cm & Spp & $P h \mathbf{c m}$ & LSR & Syqt & BMt \\
\hline Replication & 2 & 114.46 & 2155.2 & 360.5 & 2.71 & 1623.5 & 1.9 & 3865.4 & 0.10 & 96.85 & 0.19 \\
\hline cultivar & 3 & $1071.9^{*}$ & $2023.5^{*}$ & $156.62 * *$ & $5.7 * *$ & $2493.4^{*}$ & $1.75^{*}$ & $7301.7^{*}$ & $0.21^{*}$ & $103.04^{*}$ & $1.81^{*}$ \\
\hline Error & 6 & 110.8 & 2172.1 & 0 & 0.64 & 1752 & 2.84 & 1829.3 & 0.07 & 53.02 & 0.18 \\
\hline Total & 17 & & & & & & & & & & \\
\hline
\end{tabular}

$(\mathrm{p}<0.05) 50 \% \mathrm{DF}=$ days to $50 \%$ flowering, $90 \% \mathrm{DM}=90 \%$ maturity date, $\mathrm{Mbr}=$ number of prim ary branches, $\mathrm{Ppp}=\mathrm{Pod}$ per plant, $\mathrm{Pl}=\mathrm{Pod}$ length centimeter, $\mathrm{Spp}=$ seed per pod, $\mathrm{Ph}=$ plant height in centimeter, $\mathrm{LSR}=$ leaf to steam ratio, Bmyt/ha= biomass yield tone per hectare, $\mathrm{SY}=\mathrm{seed}$ yield tone per hectare, $\mathrm{Cv}=$ Coefficient of variation, $\mathrm{LSD}=$ Least significant difference, ${ }^{*}=$ significant, Ns=None significant.

Table 2. Combined mean values of different agronomic traits of four pigeon pea cultivars.

\begin{tabular}{|c|c|c|c|c|c|c|c|c|c|c|}
\hline Cultivars & $50 \%$ DF & $90 \% \mathrm{M}$ & Npbr & Ppp & Pl cm & Spp & Ph cm & LSR & Bmyt/ha & SY qt/ha \\
\hline Tsigas & $92.6 c$ & 193 & $21.6 \mathrm{a}$ & $55 a$ & $3.9 \mathrm{~b}$ & 3.5 & $104.9 \mathrm{ab}$ & $1.07 \mathrm{a}$ & $2.17 \mathrm{a}$ & 29 \\
\hline Dagagsa-75 & $124 a$ & 203 & $9.75 \mathrm{~d}$ & $89 a$ & $5.16 \mathrm{a}$ & 4.5 & $159.75 a$ & $0.69 b$ & $0.97 b$ & 23.1 \\
\hline 16555 & $109 b$ & 186 & $12.2 \mathrm{c}$ & $87 \mathrm{a}$ & $5 a$ & 4.8 & $113 \mathrm{ab}$ & $0.67 b$ & $1.27 \mathrm{~b}$ & 13.2 \\
\hline Belabas-27 & $114 \mathrm{ab}$ & 162 & $13.4 \mathrm{~b}$ & $52.5 \mathrm{a}$ & $3.14 \mathrm{~b}$ & 4.3 & $78.36 \mathrm{~b}$ & $0.74 b$ & $1.078 \mathrm{~b}$ & 13.8 \\
\hline Mean & 110 & 185.7 & 14 & 68.9 & 4.2 & 4.2 & 112.57 & 0.7 & 1.34 & 88 \\
\hline $\mathrm{CV}$ & 9.54 & 25 & 0 & 60.7 & 19 & 39.6 & 37.9 & 35 & 31.35 & 362 \\
\hline $\operatorname{LSD}(5 \%)$ & $*$ & NS & $*$ & $\mathrm{Ns}$ & $*$ & NS & $*$ & $*$ & $*$ & Ns \\
\hline
\end{tabular}

a,b,c Mean in a column within the same category having different superscripts differ significantly (p<0.05) $50 \% \mathrm{DF}=$ days to $50 \%$ flowering, $90 \% \mathrm{DM}=90 \%$ maturity date, $\mathrm{Mpbr}=$ number of primary branches, $\mathrm{Ppp}=$ Pod per plant, $\mathrm{Pl}=\mathrm{Pod}$ length centimeter, $\mathrm{Spp}=$ seed per pod, $\mathrm{Ph}=\mathrm{plant}$ height centimeter, $\mathrm{LSR}=$ leaf to steam ratio, Bmyt/ha= biomass yield tone per hectare, $\mathrm{SY}=$ seed yield tone per hectare, $\mathrm{Cv}=\mathrm{Coefficient}$ of variation, $\mathrm{LSD}=\mathrm{Least}$ significant difference, ${ }^{*}=$ significant, $\mathrm{Ns}=$ None significant. 
Table 3. Mean chemical compositions of four pigeon pea cultivars.

\begin{tabular}{llllllll}
\hline Cultivars & DM & TASH & OM & NDF & ADF & ADL \\
\hline 16527 & 91.7 & 6.7 & 85.1 & 64.4 & 40.1 & 8.5 & \\
Tsigas & 89.2 & 8.4 & 80.8 & 47.3 & 65.9 & 37.4 \\
11575 & 89.3 & 9.3 & 80.1 & 64.4 & 37.5 & 8.1 \\
16555 & 87.95 & 8.9 & 79.2 & 68.6 & 42.9 & 23.5 & 5.2 \\
\hline
\end{tabular}

$\mathrm{ADF}=$ Acid Detergent Fiber; $\mathrm{ADL}=$ Acid Detergent Lignin; $\mathrm{CP}=$ Crude Protein; NDF $=$ Neutral Detergent Fiber and OM $=$ Organic Matter; $\mathrm{TASH}=$ Total Ash; DM=Dry matter.

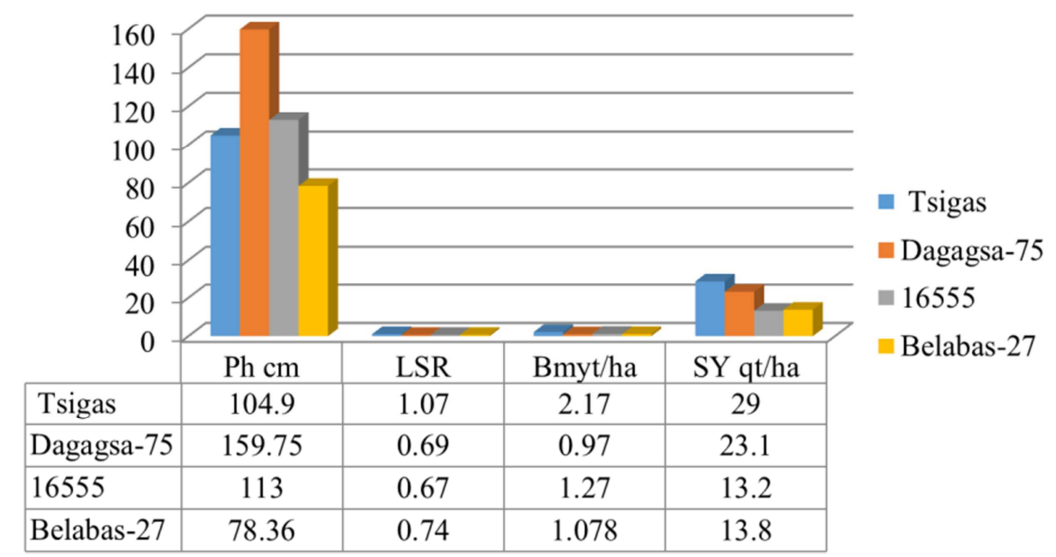

Figure 1. Mean plant height, biomass yield, leaf to steam ratio and seed yield of pigeon pea cultivars.

\section{Conclusion and Recommendations}

The result of this study indicated that cultivar Tsigas was well adapted and being productive regarding the biomass yield $(2.17 \mathrm{t} / \mathrm{ha})$, leaf to steam ratio (1.07) and seed yield (29qt/ha) and biomass yield of cultivar $16555(1.27 \mathrm{t} / \mathrm{ha})$ which is hopeful to fill the gap of low quantity ruminant feed supply of the community. In addition to the nutritional values were promising particularly the crude protein $(\mathrm{CP})$ content in cultivar Tsigas. Thus, it could be possible to conclude that the Pigeon pea cultivars Tsigas and 16555 cultivars used as a protein supplement for midland of Guji. Based up on its adaptability, high biomass yield, seed yield and good CP of cultivar Tsigas is recommended for further promotion in the midland of Guji zone and similar agro- ecologies.

\section{Acknowledgements}

The authors are grateful to the Oromia Agricultural Research Institute (IQQO) and Bore Agricultural research center for financial support to implement the study. The animal nutrition laboratory workers of Haramaya University and Debre zeyit agricultural research center were also acknowledged for their support in the chemical analysis of the feed samples.

\section{References}

[1] Samuel M, Azage T, Hegde B (2008). Labour availability and use pattern in smallholder livestock production system in Yerer watershed of Adaa Liben district: In Proceedings of the 16th annual conference of the Ethiopian Society of Animal Production (ESAP) held in Addis Ababa, Ethiopia, October 8 to $10,2008$.

[2] Legesse G, Siegmund-Schultze M, Abebe G (2010). Economic performance of small ruminants in mixed-farming systems of Southern Ethiopia. Tropical Animal Health Production World Journal of Dairy and Food Science 4 (2): 185-192.

[3] Sefa S (2017). Estimation of feeds and fodders for livestock population of Ethiopia and mitigation of feed shortage. Journal of Natural Science and Research 7 (11): 45-49

[4] Central statistical agency (CSA), 2017. Agricultural sample survey 2016/2017 (2009 E.C). volume I report on area and production of major crops (private peasant holdings, Meher season), Addis Ababa.

[5] Alemayehu M, Gezahagn K, Fekede F, Getnet A (2017). Review on major feed resources in Ethiopia: conditions, challenges and opportunities. Agricultural. Science and Research 5 (3): 176-185.

[6] Zewdie W (2010). Livestock production systems in relation with feed availability in the highlands and central rift valley of Ethiopia. An MSc thesis presented to Haramaya University. $160 \mathrm{p}$.

[7] Melese G, Berhan T, Mengistu U (2014). Effect of supplementation with non-conventional feeds on feed intake and body weight change of Washera sheep fed urea treated finger millet straw. Greener Journal of Agricultural Science 4 (2): 067-074.

[8] Multipurpose, drought resistant forage, grain and vegetable crop for sustainable southern farms. Natural resources forum 31: 297 - 305. New crop for the southeastern United States. In: J. Janick and J. E. Simon (eds.).

[9] Rao, S. C., Coleman, S. W., Mayeux, H. S., 2002. Forage production and nutritive value of selected pigeonpea ecotypes in the southern greatplains. Crop Science, 42: 1259-1263. 
[10] Bekele-Tessema, A., 2007. Profitable agroforestry innovations for eastern Africa: experience from 10 agroclimatic zones of Ethiopia, India, Kenya, Tanzania and Uganda. World Agroforestry Centre (ICRAF), Eastern Africa Region

[11] Crop Trust, 2014 Crop Trust, 2014. Pigeon Pea: Food for Drought. www.croptrust.org.

[12] Phatak, S. C. Nadimpalli, R. G. Tiwari, S. C. Bhardwaj, H. L., 1993. Pigeon peas: Potential Pigeon pea (Cajanus cajan). Journal of the Science of Food and Agriculture 50: 201-209.

[13] Orwa, C.; Mutua, A.; Kindt, R.; Jamnadass, R.; Anthony, S., 2009. Agroforestree Database: a tree reference and selection guide version 4.0. World Agroforestry Centre, Kenya

[14] Cook, B. G.; Pengelly, B. C.; Brown, S. D.; Donnelly, J. L.; Eagles, D. A.; Franco, M. A. ; Hanson, J.; Mullen, B. F.; Partridge, I. J.; Peters, M.; Schultze-Kraft, R., 2005. Tropical forages. CSIRO, DPI\&F(Qld), CIAT and ILRI, Brisbane, Australia

[15] Damaris, A. O. (2007). The potential of pigeon pea (Cajanus Cajan (L.) Millsp.) In Africa. Editions. SAS Institute Inc., Cary, NC, USA

[16] ICRISAT (2009) Socioeconomic Assessment of Baseline Pigeon pea and Groundnut Production

[17] Yazachew E, Kasahun D (2011). The National regional government of Oromia, Physical and socio economic profile of Guji zone districts. Bureau of Finance and Economic Development. The National Regional Government of Oromia, Addis Abeba.

[18] AOAC (Association of Official Analytical Chemists). 1995. Official Methods of Analysis. PP. 5-13. (16th edition), Washington DC, USA. Araújo, G. G. L. does Socorro, E. P. Oliveira, and R.
[19] Van Soest PJ, Robertson JB (1985). Analysis of Forages and Fibrous Foods. A Laboratory manual for Animal Science 613. Cornel University, Ithaca. New York, USA, P. 202.

[20] Statistical Analysis System (SAS). 2002. SAS/STAT guide for personal computers, version 9.0 the national Regional Government of Oromia, Addis Abeba

[21] James AD, (1983). Cajanus cajan (L.) Millsp. Handbook of Energy Crops. S, Sharma TR, Rosen B, Carrasquilla-Garcia N, Farmer AD, Dubey A, Saxena KB, Gao J, Fakrudin B, Singh MN, Singh BP, Wanjari KB, Yuan M, Srivastava RK, Kilian A, Upadhyaya

[22] Varshney RK, Close TJ, Singh NK, Hoisington DA, Cook DR: Orphan legume crops enter the genomics era!. Curr Opin Plant Biol. 2009, 11: 1-9. Ezeaku et al.,(2016). The Journal of Animal \& Plant Sciences, 26 (1): 2016, Page: 163-169.

[23] Remanandan P, Sastry DVSSR, Mengesha MH. ICRISAT Pigeon Pea Germplasm Catalog: Evaluation and Analysis. Pantacheru AP. India, ICRISAT, 1988; 40.

[24] Chattopadhyay, K. and K. R. Dhiman, 2006. Characterization, variability, diversity and path coefficient analysis of pigeon pea genotypes. Indian J. Genet., 34: 56-63.

[25] Dahat DV, Deshmukh RB, Patil JV (2006). Genetic variability and character association in pigeon pea grown as sole and intercrop in pearl millet. Indian J. Agric. Res., 34: 413-420.

[26] Sharma D. Reddy LJ. Green JM, Jain KC. International Adaptation of Pigeon Peas. In: Proceedings of the International Workshop on Pigeon peas. ICRISAT Centre, India. Pantacheru AP, India, ICRISAT. 1981; $71-81$. 